Informatika i sistemy upravleniya. - 2019. - No. 4(62). - P. 3-9.

Drachev K.A., Rimlyand V.I. (riml@ pnu.edu.ru), Molokanov B.M.

Pacific state university

\title{
APPLICATION OF THE FINITE ELEMENT METHOD IN THE STUDY OF ACOUSTIC FIELDS
}

The paper considers the possible application of the finite element method to construct acoustic fields in 2- and 3-dimensional spaces. Examples of the numerical simulation are given, as well as the comparison with the results of the real experiment and with the results of Finite Difference Time Domain application. Close agreement is achieved for both wave fronts and velocities of various wave types. Keywords: finite element method, acoustics, modeling, composite material.

DOI: 10.22250/isu.2019.62.3-9

\section{For citation:}

Drachev K.A., Rimlyand V.I., Molokanov B.M. APPLICATION OF THE FINITE ELEMENT METHOD IN THE STUDY OF ACOUSTIC FIELDS // Informatika i sistemy upravleniya. - 2019. No. 4(62). - P. 3-9. 